\title{
Impact of merger on bank performance
}

\begin{abstract}
Joginder Goet

In this study, accounting ratios has been used to analyze the financial performance of Citizens Bank International Ltd. in Nepal before and after merger. I have analyzed their financial statements for six years by using various ratios. In spite of certain limitations, accounting ratios are still considered as a convenient and reliable analytical tool. Ratio analysis, being a time-tested technique, is most frequently employed in all financial decision-making processes. The results show that the financial performance of $\mathrm{CBI} \mathrm{Ltd}$. in the areas of profitability and stability has been most satisfactory after merger. It means that merger deal success to improve the financial performance of the bank.
\end{abstract}

Keywords: CBI Ltd., profitability, merger, financial performance, accounting ratios, decision-making

\section{Introduction}

The present globalized economy, mergers and acquisitions (M\&A) are all things considered dynamically used the world over for improving the force of associations through expanding progressively essential bit of the pie, extending the portfolio to reduce business risk, for entering new markets and geographies, and profiting by economies of scale, etc. The goals behind mergers and acquisitions are economy of scale, economy of expansion, increase bit of the general business and salaries, charge evaluation, coordinated effort, land, and other development. Because of these reasons, banks met with one another or centered by verifying bank. Recently, the Nepalese cash related portion and the entire economy has been the middle both in the business floats and in the media, with respect to amazing challenges being stood up to. Authoritative measures are being taken at both littler scale level as well as the huge scale financial level to improve the future condition of the different fragments, which are under cash related weight or under budgetary crises.

Most of the research on mergers has focused on the strategic and financial fit between the acquirer and the acquired firms, though some research has dealt with the integration of various organizational systems, such as technology and management control systems (Shrivastava, 1986). Most of the studies attempting to identify the factors that affect the success of mergers as a strategic alternative mention the importance of more subtle issues (Jemison \& Sitkin 1986; Lubatkin, 1983, 1987; Marks, 1982). However, there appears to be a gap between the research

* Asst. Professor Shanker Dev Campus Trubhuvan University, Nepal Email ID: goetj15@gmail.com 
about the various classifications of mergers and the research about the role culture plays in the overall implementation of mergers.

The mergers and acquisition play a significant role in the banking and industrial sector of any economy. The objective of this investigation considers the impact of merger of two banks. This examination is quantitative research to give learning into the examples that have extended the merger.

\section{Research hypothesis}

The following null and alternative hypotheses have been formulated to test the objectives of the study:

Ho: There is no significant difference between the pre and post-merger financial performance of the bank.

H1: There is a significant difference between the pre and post-merger financial performance of the bank.

\section{Literature review}

Jensen's (1986) hypothesis, some M and A are intended to decrease regulatory inefficient viewpoints that come about because of holding free cash streams not appropriated to proprietors. Evidence that financial specialists of target firms recognize positive irregular returns in perspective on M and A is unambiguous (Halpem 1983; Jensen \& Ruback, 1983; Schipper \& Thompson, 1983). Meanwhile, results concerning the stock execution of bidder firms are questionable. A few examinations record positive little returns and others report no plenitude returns or negative ones (in particular, Schipper \& Thompson, 1983, Table 9). The wave of merger and acquisition is appropriately moving without there being many reasons for cash related execution to legitimize such movement (Schenk, 2000).

Ordinary discoveries from these early examinations recommended that acquisitions did not update getting firm regard, as evaluated by either present moment (Asquith, 1983; Dodd, 1980; Jarrell \& Poulsen, 1989; Malatesta, 1983) or long-term performance measures (Agrawal, Jaffe, \& Mandelker, 1992; Asquith, 1983; Loderer Martin, 1992). Even more expressly, acquisitions were every now and again found to disintegrate acquiring firm regard (Chatterjee, 1992; Datta, Pinches, \& Narayanan, 1992; King, Dalton, Daily, \& Covin, 2004; Moeller, Schlingemann, \& Stulz, 2003; Seth, Song, \& Pettit, 2002) and produce significantly unpredictable market returns (Langetieg, Haugen, \& Wichern, 1980; Pablo, Sitkin, \& Jemison, 1996).

Ojha, and Walsh (2016) have expected that merger and acquisition of money related relationship in Nepal has been advanced in the consistent years and is in expanding plan. It is in light of the way that Merger in the ceaseless years has helped a broad fragment of the money related establishments to build the capital likewise as help them to finish being 
powerfully commanding. The most gigantic outcome after a merger is the additional security of consumers right. Together with it, the budgetary part itself has wound up being acceptably arranged to verify itself even in fundamental money related position. This demonstrates the achievability of merger and getting framework acknowledged in Nepal. Bhatta (2016) examined that the mergers incited changes in banks "share ownership". Banks capability increases with continuously capable and mixed considerations. Excess of capital enables to fight decidedly with outside banks that are glad to go into the Nepalese market very soon. Krishnamurthy and Alkhathlan (2010) express that the results on the post-merger execution prescribe that banks are winding up progressively based on their high net premium pay practices and the guideline reason behind their mergers is relative up their exercises.

Singh (2015) has been attempted to separate whether the ICICI Bank has accomplished money related execution capability in the midst of the post-merger period in the district of profitability, budgetary impact, liquidity, and capital market measures. The examination has followings destinations. To analyze the impact of the merger of Bank of Rajasthan on the financial performance of ICICI Bank. To separate the effect of merger of Sangli Bank on the money related execution of ICICI Bank. The Major disclosures were the examination of table present that, in Profitability, Standards expect ROE and Ratio of Operating Profit to Total Assets each other extent Net Profit Margin, ROA, ROI and Return on Advances the p-value is merely unmistakable than 5 percent. Along these lines the invalid hypothesis "There is no huge distinction in Profitability Standards among pre and post-M and A" in regard of these proportions is recognized. It is contemplated that there has been a critical distinction in the estimation of ROE and Ratio of Operating Profit to Total Assets after converging with Sangli Bank.

Malik et al. (2014) had led an examination on the critical targets were the principal objective of the examination is a firm behind going into the plan of merger and verifying is to work with various associations that can be progressively beneficial when appeared differently in relation to work alone in a market. Mergers and acquisitions are an overall business technique that enables firms to go into new potential markets or to another business zone.

\section{Methodology}

The purpose of the study is to answer "Does merger of the banks improves the profitability?" It also explores the effect of merger on profitability of the bank by using different accounting rations. For this purpose, profitability ratios and stability ratios have been considered as the most reliable and efficient ratios to check the profitability of the bank. These accounting ratios also help in making rational decisions and future planning for the betterment of the bank. 


\section{Research design}

The study has used descriptive and correlational research design to test the objectives of the study. It relies upon discretionary data that is collected form yearly reports of picked banks. Citizen international bank has been taken as a sample bank for the purpose of the study. The bank has been chosen as a purposive technique out of twenty seven commercial banks in Nepal. The study has used six year data consisting of three years pre and three year postmerger data for the purpose of analysis.

For measuring the financial and operating performance of the merger and acquisition, different ratios have been considered to evaluate the impact of mergers. In this study, deals with the merger of selected two banks. In order to analyses the financial performance of banks pre and post-merger, the financial and accounting ratios like Net Profit Margin, Return on Assets, ROE, Cost to Income Ratio, Price Earnings Ratio, etc. have been used.

\section{Results and discussion}

With the help of financial data available in audited statements of CBI Ltd., six years accounting ratios have been computed as per formulae before merger and after merger. These accounting ratios including profitability ratios and stability ratios have been computed. These ratios are shown in tables.

\section{Table 1}

Percentage of change of different parameters of CBI Ltd.

\begin{tabular}{|c|c|c|c|c|}
\hline Total Mean & Pre- Merger & Post-Merger & Change & Relative Change (\%) \\
\hline NPM & 15.07 & 20.89 & 5.62 & 37.29 \\
\hline ROA & 1.57 & 1.92 & 0.35 & 22.29 \\
\hline EPS & 18.02 & 23.63 & 5.61 & 31.13 \\
\hline P/E Ratio & 19.27 & 18.18 & -1.09 & -5.66 \\
\hline ROE & 15.10 & 14.36 & -0.74 & -4.90 \\
\hline CAR & 13.12 & 14.37 & 1.25 & 9.53 \\
\hline CDR & 81.63 & 90.08 & 8.45 & 10.35 \\
\hline CASA & 26.25 & 24.43 & -1.82 & -6.93 \\
\hline CI Ratio & 35.51 & 37.75 & 2.24 & 6.31 \\
\hline
\end{tabular}

Source: (Researcher Computed)

After the calculation of different financial indicators of the bank in the pre-merger era and post-merger periods, it was found that the average values for different variables like NPM, ROA, EPS, CAR, CAR, cost to income ratios have recorded a positive change. The mean value of NPM, ROA, EPS, CAR, CDR, and CI ratio during the pre-merger period is 15.07, 1.57, $18.02,13.12,81.63$, and 35.51 and during the post-merger period is $20.89,1.92,23.63,14.37$, 90.08 , and 37.75 respectively. These ratios are increased by $37.29 \%, 22.29 \%, 31.13 \%, 9.53 \%$, $10.35 \%$, and $6.31 \%$ respectively that is a significant change. 
However, $\mathrm{P} / \mathrm{E}$ ratios, ROA and CASA have recorded a negative change. The mean value of $\mathrm{P} / \mathrm{E}$ ratio, $\mathrm{ROE}$, and CASA ratio during the pre-merger period is 19.27, 15.10, and 26.25 and during the post-merger period is $18.18,14.36$, and 24.43 respectively. These ratios are decreased by $5.66 \%, 4.90 \%$, and $6.93 \%$ respectively that is not a significant change. If we look only the relative change percentage in these financial indicators, the result shows that postmerger was found to be improved to pre-merger. After the merger, the most important ratio of financial indicators i.e. NPM, ROA, and EPS have positive change but another indicator of ROE has negative change, which indicates us it is satisfactory.

Table 2

Mean and standard deviation of Citizens Bank International Limited

\begin{tabular}{|c|c|c|c|c|c|c|}
\hline & & Mean & SD & t- value & P-value & Interpretation \\
\hline \multicolumn{7}{|c|}{ Profitability Ratios } \\
\hline \multirow{2}{*}{ NPM } & Pre & 15.07 & 3.21 & \multirow{2}{*}{1.348} & \multirow{2}{*}{0.125} & \multirow{2}{*}{ NS } \\
\hline & Post & 20.69 & 4.95 & & & \\
\hline \multirow{2}{*}{$\mathrm{ROA}$} & Pre & 1.57 & 0.25 & \multirow{2}{*}{1.441} & \multirow{2}{*}{0.112} & \multirow{2}{*}{ NS } \\
\hline & Post & 1.92 & 0.23 & & & \\
\hline \multirow{2}{*}{ EPS } & Pre & 18.02 & 5.43 & \multirow{2}{*}{0.789} & \multirow{2}{*}{0.237} & \multirow{2}{*}{ NS } \\
\hline & Post & 23.63 & 8.46 & & & \\
\hline \multicolumn{7}{|c|}{ Performance Indicators } \\
\hline \multirow{2}{*}{ P/E Ratio } & Pre & 19.27 & 4.97 & \multirow{2}{*}{0.343} & \multirow{2}{*}{0.375} & \multirow{2}{*}{ NS } \\
\hline & Post & 18.18 & 2.46 & & & \\
\hline \multirow{2}{*}{ ROE } & Pre & 15.10 & 3.73 & \multirow{2}{*}{0.186} & \multirow{2}{*}{0.431} & \multirow{2}{*}{ NS } \\
\hline & Post & 14.36 & 4.24 & & & \\
\hline \multirow{2}{*}{ CAR } & Pre & 13.12 & 1.06 & \multirow{2}{*}{0.828} & \multirow{2}{*}{0.227} & \multirow{2}{*}{ NS } \\
\hline & Post & 14.37 & 1.87 & & & \\
\hline \multicolumn{7}{|c|}{ Efficiency Indicators } \\
\hline \multirow{2}{*}{ CDR } & Pre & 81.63 & 1.88 & \multirow{2}{*}{3.221} & \multirow{2}{*}{0.016} & \multirow{2}{*}{ S } \\
\hline & Post & 90.08 & 3.19 & & & \\
\hline \multirow{2}{*}{ CASA } & Pre & 26.25 & 3.02 & \multirow{2}{*}{0.756} & \multirow{2}{*}{0.246} & \multirow{2}{*}{ NS } \\
\hline & Post & 24.43 & 1.56 & & & \\
\hline & Pre & 35.51 & 8.48 & & O 361 & \\
\hline Cl Ratio & Post & 37.75 & 5.59 & 0.427 & 0.361 & NS \\
\hline
\end{tabular}

Note: Researcher's compilation based on tables 1 and 2; *S stands for significant values, NS stands for non-significant values.

According to the Table 1, it has illustrated the mean value of NPM, ROA, and EPS are increased after the merger by $37.29 \%, 22.29 \%$, and $31.13 \%$ respectively. The descriptive table shows $(\mathrm{t}$ $=1.348, \mathrm{p}=0.125>0.05)$ of NPM, $(\mathrm{t}=1.441, \mathrm{p}=0.112>0.05)$ of ROA, $(\mathrm{t}=0.789, \mathrm{p}=0.237>$ 0.05 ) of EPS. These three profitability ratios indicator is negative so the null hypothesis (Ho) is accepted which leads us to infer that there is no significant difference between pre and post-merger period. 
More ever, the $\mathrm{P} / \mathrm{E}$ ratio and ROE mean value of the bank is decreased by $5.66 \%$ and $4.90 \%$ with $(t=0.343, p=0.375>0.05)$ and $(t=0.186, p=0.431>0.05)$ respectively, which is not significant. Another indicator, capital adequacy ratio is increased by $9.53 \%$ with $(t=0.828$, $p=0.227>0.05)$. Three results that, there is no significant difference between pre and postmerger. A performance indicator is also rejected H1 (alternate hypothesis).

In accordance with the above table 2, the mean value of credit deposit ratio is increased by $10.35 \%$ with $(t=3.221, p=0.016<0.05)$, which indicates the positive result of a merger. Here, $\mathrm{H} 1$ (alternate hypothesis) is accepted. On other hand, the mean value of CASA is decreased by $6.93 \%$ with $(t=0.756, p=0.246>0.05)$. Cost to Income ratio's mean value is also increased by $6.31 \%$ with $(t=0.427, p=0.361>0.05)$. Cost to income ratio is not statistically significant so accepted Ho (null hypothesis).

\section{Conclusion}

The results reveal that post-merger most of the financial parameters have not exhibited any basic improvement in the both of cases while a couple of parameters have shown enormous improvement yet it may be possible that there is an improvement in these extents in later years as only three years financial extents are considered. While overseeing mergers and acquisitions, agreeable vitality increments are made as time goes on achieving the improvement in the profitability and execution of banks. Consequently, it might be assumed that there are bright outcomes of mergers and acquisitions on the budgetary presentation of the banks.

Merger and acquisitions in not using all means the main the blending framework offered to bank associations, plots, cross-shareholdings, etc. could offer a choice a fundamental response to expanding topographically and cross over sections. These elective fundamental responses could, in any case, lead to a request with respect to the perfect level of a joint effort that empowers banking establishments to benefit from their central focuses.

\section{References}

Agrawal, A., Jaffe, J. F., \& Mandelker, G. N. (1992). The post-merger performance of acquiring firms: A reexamination of an anomaly. Journal of Finance, 47(4), 1605-1621.

Asquith, P. (1983). Merger Bids, Uncertainty, and Stockholder Returns. Journal of Financial Economics, 11 (1-4), 51-83.

Bhatta, M. K. (2016). Effect of bank merger on the shareholders' wealth and post-merger situation of Nepalese banking industry. Information Management and Business Review, $8(4), 41-51$.

Chatterjee, S. (1992). Sources of value in takeovers: Synergy or restructuring implications for target and bidder firms. Strategic Management Journal, 13(4), 267-286.

Datta, D. K., Pinches, G. E., \& Narayanan, V. K. (1992). Factors influencing wealth creation from mergers and acquisitions - A meta-analysis. Strategic Management Journal, 13(1), 67-84. 
Dodd, P. (1980). Merger proposals, management discretion and stockholder wealth. Journal of Financial Economics, 8(2), 105-137.

Halpem, P. (1983). Corporate Acquisitions: A Theory of Special Cases? A Review of Event Studies Applied to Acquisitions. The Journal of Finance, 38(2), 297-317.

Jarrell, G. A., \& Poulsen, A. B. (1989). The returns to acquiring firms in tender offers: Evidence from 3 decades. Financial Management, 18(3), 12-19.

Jemison, D. B., \& Sitkin, K. (1986) Corporate acquisitions: A process perspective. Academy of Management Review, 11(1), 145-163.

Jensen, M. C., \& Ruback, R. S. (1983). The Market for Corporate Control: The Scientific Evidence. Journal of Financial Economics, 11(4), 45-50.

Jensen, M.C. (1986). Agency Costs of Free Cash Flow, Corporate Finance and Takeovers. American Economic Review Papers and Proceedings, 76(2), 323-329.

King, D. R., Dalton, D. R., Daily, C. M., \& Covin, J. G. (2004). Meta-analyses of post-acquisition performance: Indications of unidentified moderators. Strategic Management Journal, 25(2), 187-200.

Krishnamurthy, R. \& Alkhathlan, K. (2010). Market based mergers-study on Indian and Saudi Arabian banks. International Research Journal Economics and Finance, 37(2), 147-154.

Langetieg, T. C., Haugen, R. A., \& Wichern, D. W. (1980). Merger and stockholder risk. Journal of Financial and Quantitative Analysis, 15(3), 689-717.

Loderer, C., \& Martin, K. (1992). Post-acquisition performance of acquiring firms. Financial Management, 21(3), 69-79.

Lubatkin, M. (1983). Merger and the performance of the acquiring firm. Academy of Management Review, 8 (2), 218-225.

Lubatkin, M. (1987). Merger strategies and stockholder value. Strategic Management Journal, $8(1), 39-53$.

Malatesta, P. H. (1983). The wealth effect of merger activity and the objective functions of merging firms. Journal of Financial Economics, 11(1-4), 155-181.

Malik, M. F., Anuar, M. A., Khan, S., \& Khan, F. (2014). Mergers and Acquisitions: A Conceptual Review. International Journal of Accounting and Financial Reporting, 4 (2), 520-533. DOI: https:// doi.org/10.5296/ijafr.v4i2.6623

Marks, M. L. (1982). Merging human resources: A review of current research. Mergers and Acquisitions, 17(2), 38-44.

Moeller, S. B., Schlingemann, F. P., \& Stulz, R. M. (2003). Do shareholders of acquiring firms gain from acquisitions? NBER Working Paper No. W9523. Retrieved December 1, 2007, from http://ssrn.com/abstract $=385023$ 
Ojha, S., \& Walsh, J. (2016). Merger policy and its impact on Nepalese banks. International Review of Management and Development Studies, 1(2), 117-134.

Pablo, A. L., Sitkin, S. B., \& Jemison, D. B. (1996). Acquisition decision-making processes: The central role of risk. Journal of Management, 22(5), 723-746.

Schenk, H. (2000). The performance of banking mergers: Propositions and policy implications. In UNI-Europa Finance The Impact of Mergers and Acquisitions in Finance on Workers, Consumers, and Shareholders, Geneva, Union Network International.

Schipper, K., \& Thompson, R. (1983). Evidence on Capitalized Value of Merger Activity for Acquiring Firms. Journal of Financial Economics, 11(1-4), 85-119.

Seth, A., Song, K. P., \& Pettit, R. R. (2002). Value creation and destruction in cross-border acquisitions: An empirical analysis of foreign acquisitions of US firms. Strategic Management Journal, 23(10), 921-940.

Shrivastava, P. (1986). Post-merger integration. Journal of Business Strategy, 7(1), 65-76.

Singh, S. (2015). Mergers in service sectors: Post-merger financial analysis of ICICI bank. International Journal of Applied Research, 1(9), 485-488. 